$1 \quad \mathbf{P M}_{2.5}$ Source Apportionment Using Organic Marker-based CMB

2 Modeling: Influence of Inorganic Markers and Sensitivity to Source

\title{
3 Profiles
}

4

5 Yingze Tian', Xiaoning Wang ${ }^{1}$, Peng Zhao ${ }^{1}$, Zongbo Shi ${ }^{2}$, Roy M. Harrison ${ }^{* 2 a}$

$7{ }^{1}$ State Environmental Protection Key Laboratory of Urban Ambient Air Particulate Matter Pollution

8 Prevention and Control, College of Environmental Science and Engineering, Nankai University,

$9 \quad$ Tianjin, 300071, China

10

$11{ }^{2}$ School of Geography Earth and Environmental Science, University of Birmingham, Edgbaston,

Corresponding author: Roy M. Harrison (r.m.harrison@bham.ac.uk) 


\section{ABSTRACT}

Chemical mass balance $(\mathrm{CMB})$ is one of the most popular methods to apportion the sources of $\mathrm{PM}_{2.5}$. However, the source apportionment results are dependent on the choices of measured chemical species and the source profiles. Here, we explore the sensitivity of CMB results to source profiles by comparing CMB modeling based on organic markers only (OM-CMB) with a combination of organic and inorganic markers (IOM-CMB), using organic and inorganic markers in $\mathrm{PM}_{2.5}$ samples collected in the Chinese megacity of Chengdu. OM-CMB results show that gasoline vehicles, diesel vehicles, industrial coal combustion, resuspended dust, biomass burning, cooking, vegetation detritus, SOA, sulphate, and nitrate contributed to $4 \%, 10 \%, 15 \%, 12 \%, 5 \%, 3 \%, 4 \%, 9 \%, 10 \%$, and $20 \%$, in comparison to $4 \%, 11 \%, 15 \%, 17 \%, 6 \%, 2 \%, 5 \%, 10 \%, 7 \%$, and $18 \%$ from IOM-CMB modelling. The temporal variations of $\mathrm{PM}_{2.5}$ contributions from sulphate, nitrate, SOA, gasoline vehicles, and biomass burning, characterized by unique markers and low collinearity, were in good agreement between the OM-CMB and IOM-CMB results. However, resuspended dust estimates from OM-CMB had a poor correlation with that from IOM-CMB, due to the different tracers used. When replacing the source profile for industrial coal combustion with that for from residential sources, the contributions of resuspended dust and residential coal combustion were overestimated because the residential coal combustion profile contained a higher concentration of OC and organic compounds but lower crustal elements. Different source profiles for gasoline vehicles were also evaluated. Our results confirm the superiority of combining inorganic and organic tracers and using up-to-date locally-relevant source profiles in source apportionment of PM.

Keywords: particulate matter, source apportionment, CMB model, organic marker 


\section{INTRODUCTION}

Atmospheric fine particles $\left(\mathrm{PM}_{2.5}\right)$ have long been shown to have pronounced effects on human health (Bell et al., 2014; Yang et al., 2019; Hong et al.,2021; Li et al., 2022; Wen et al., 2022). PM2.5 control is a challenging problem, especially in megacities where large populations are exposed to high concentrations. The information on the impacting sources can play an important role in designing effective $\mathrm{PM}_{2.5}$ reduction strategies. Many studies have estimated the potential source contributions to $\mathrm{PM}_{2.5}$ in megacities using various methods, such as receptor models (Lu et al., 2018; Wang et al., 2013; Perrone et al., 2012; Mor et al., 2021; Song et al., 2021; Zhang et al., 2021a), and air quality models (Clappier et al., 2015; Zhang et al., 2017; Li et al., 2020a; Guan et al., 2021). Among the receptor models, the chemical mass balance $(\mathrm{CMB})$ model approach has been used for source apportionment of PM at many locations, worldwide (Zheng et al., 2002; Perrone et al., 2012; Yin et al., 2015; Chen et al.,2015; Lu et al., 2018; Wu et al., 2020; Wong et al., 2021). This model has some underlying challenges posed by possible collinearity of source profiles, and relevance of source profiles.

$\mathrm{PM}_{2.5}$ is comprised of a complex mixture of chemical components, including both inorganic and organic components. As a significant constituent of $\mathrm{PM}_{2.5}$, organic matter (OM) is comprised of thousands of compounds which show distinctive physical and chemical properties (Zhang et al., 2013; Zhao et al., 2013; Li et al., 2020b; Cao et al., 2021; Li et al., 2021). Generally, the OM is composed of primary organic matter (POM) which is directly emitted, and secondary organic matter (SOM) which is formed through the chemical oxidation of volatile organic compounds (VOCs) (Yang et al., 2016; Zhan et al., 2021; Zhang et al., 2021b). Numerous studies on $\mathrm{PM}_{2.5}$ source apportionment have been conducted based upon inorganic markers and OC (Olson et al., 2008; Li et al., 2020c). However, 
81

many important $\mathrm{PM}_{2.5}$ emission sources (such as cooking) do not have a unique composition (Zhao et al., 2015). Some organic compounds are more specific to individual PM sources and have been used as molecular markers in source apportionment models (Marmur et al., 2006; Schauer and Cass, 2000; Schauer et al., 1996; Robinson et al., 2006; Chow et al., 2007; Arhami et al., 2018; Esmaeilirad et al., 2020; Tian et al., 2021a; Mancilla et al., 2021). An organic molecular marker-based chemical mass balance (OM-CMB) method has been widely used to quantify source contributions to carbonaceous aerosols. The OM-CMB method performs well in the source apportionment of OC, but does not directly estimate contributions of inorganic secondary ions when apportioning $\mathrm{PM}_{2.5}$ sources (Ke et al., 2008). Thus, it is advantageous to explore the influence of using both inorganic and organic markers in the $\mathrm{CMB}$ modeling of $\mathrm{PM}_{2.5}$.

Several studies have applied the OM-CMB model for source apportionment of PM in China (Zheng et al., 2005; Liu et al., 2016; Guo et al., 2013; Wang et al., 2009; Wu et al., 2020; Xu et al., 2021). However, the organic source profiles they used were mainly derived from measurements made in the United States, which may be less representative of the local sources and current conditions of the sources in China.

Therefore, this paper aims at exploring the influence of introducing inorganic markers, and the sensitivity to source profiles. $\mathrm{PM}_{2.5}$ source apportionment was conducted by CMB modeling based on organic markers (OM-CMB) and by a combination of organic and inorganic markers (IOM-CMB). Commonly used markers (including OC, EC, ions, elements) and organic markers (including polycyclic aromatic hydrocarbons (PAHs), n-alkanes, hopanes, levoglucosan, palmitic acid, stearic acid, and cholesterol) in $\mathrm{PM}_{2.5}$ collected in a Chinese megacity were analysed. Source apportionment 
of $\mathrm{OC}$ was conducted by the OM-CMB approach, and then the other source contributions to $\mathrm{PM}_{2.5}$ were indirectly estimated. In addition, source apportionment of $\mathrm{PM}_{2.5}$ was directly conducted by the IOM-CMB method, and source contributions to $\mathrm{PM}_{2.5}$ estimated by the OM-CMB and the IOM-CMB methods were compared. In addition, the sensitivity to different source profiles for coal combustion and gasoline vehicles were tested.

\section{METHODS AND MATERIALS}

\subsection{Sampling}

$\mathrm{PM}_{2.5}$ samples were collected from a megacity in China, Chengdu $\left(102^{\circ} 54^{\prime}\right.$ to $104^{\circ} 53^{\prime} \mathrm{E}, 30^{\circ} 05^{\prime}$ to $31^{\circ} 26^{\prime} \mathrm{N}$ ), from January to December in 2018. The city is located in Southwestern China with a population of more than 14 million. As the capital of Sichuan province, Chengdu is a centre of economic development and transportation in Southwestern China, with continuous development of industry and changes in traffic conditions (Shi et al., 2015; Liu et al., 2015).

The sampling site is at the Environmental Protection Building (EPB, $\left.104^{\circ} 04^{\prime} \mathrm{E}, 30^{\circ} 35^{\prime} \mathrm{N}\right)$, which is located in a mixed residential and commercial area of the downtown city (Shi et al., 2017). There is no obvious industrial emission near the building. The sampling points are located on the rooftop of the EPB building, which is approximately $25 \mathrm{~m}$ above ground level. Daily samples were collected and each sampling lasted for $22 \mathrm{~h}$. The sampling was stopped during rainy days. There were $64 \mathrm{PM}_{2.5}$ samples collected during the whole year, involving spring (March, April and May), summer (June, July and August), autumn (September, October and November), and winter (January, February and December). The dry season (Jan. to Apr., Dec.) and wet season (Jun. to Oct.) were both well represented. 
The samples were collected using two medium-volume air samplers (TH-150, Wuhan Tianhong, China) with a flow rate of $100 \mathrm{~L} / \mathrm{min}$. Polypropylene $(90 \mathrm{~mm}$ in diameter) and quartz filters $(90 \mathrm{~mm}$ in diameter) were used to collect particulate matter. After sampling, the quartz filters were kept in aluminum foil bags and stored at $-4^{\circ} \mathrm{C}$.

\subsection{Chemical analysis and quality assurance and quality control (QA/QC)}

The following source tracer components were analysed: OC, EC, ions, elements, PAHs, n-alkanes, hopane, levoglucosan, fatty acids, and cholesterol. The particles collected on the polypropylene filters were used for the analysis of elements including $\mathrm{Si}, \mathrm{Ca}, \mathrm{Al}$ by inductively coupled plasma-mass spectrometry (ICP-AES) (IRIS Intrepid II, Thermo Electron). A 1/4 section of each filter was placed into an acid solution $\left(\mathrm{HNO}_{3}: \mathrm{HCl}: \mathrm{H}_{2} \mathrm{O}_{2}=1: 3: 1\right)$. The quartz filters were used for the analysis of the water-soluble ions $\left(\mathrm{NH}_{4}{ }^{+}, \mathrm{Cl}^{-}, \mathrm{NO}_{3}{ }^{-}\right.$and $\left.\mathrm{SO}_{4}{ }^{2-}\right)$ and carbon fractions (OC and EC). A 1/8 portion of each filter was cut and placed in a centrifuge tube with $8 \mathrm{ml}$ of distilled deionized water and the solutions were refrigerated for 24 hours, filtered and analyzed with a Thermo ICS900 Ion Chromatograph (Thermo Electron) (Tian et al., 2013). Carbon components were measured by a thermal/optical carbon aerosol analyzer (DRI 2001A, Atmoslytic Inc.) based on the IMPROVE thermal/optical reflectance (TOR) protocol.

Organic compounds, including 11 n-alkanes, 17 PAHs, 3 hopanes, 2 fatty acids, levoglucosan and cholesterol, were measured by gas chromatography-mass spectrometry (GC-MS). The full names and corresponding abbreviations of the components are summarized in Table 1.

A 1/4 of each quartz filter was cut and put into a tube prior to analysis of PAHs, n-alkanes, and hopane. 
It underwent a sonicated extraction with $20 \mathrm{~mL}$ dichloromethane and $\mathrm{n}$-hexane (v/v 1:1) under ice bath conditions twice, each for $15 \mathrm{~min}$, and filtration into a round-bottomed flask by a $0.22 \mu \mathrm{m}$ filter. After passage through a pre-activated solid phase extraction cartridge and elution with n-hexane, the solution was concentrated under reduced pressure on a rotary evaporator to near dryness (less than 5 $\mathrm{ml}$ ). Finally, the volume was reduced to $1 \mathrm{ml}$ after a slow nitrogen blow. The internal standards (naphthalene-d8, acenaphthene-d10, phenanthrene-d10, chrysene-d12, and perylene-d12; hexamethylbenzene; n-tetracosane-d50) were added to the samples and the samples were stored at under $-4{ }^{\circ} \mathrm{C}$ in darkness until analysis (Liu et al., 2015).

Another $1 / 4$ of the quartz filters was cut and put into tubes to analyze fatty acids and cholesterol. Fifteen $\mathrm{ml}$ methanol and $10 \mathrm{ml}$ dichloromethane (v/v 1:2) were added into the tubes and sonicated, then extracted for 10 min 3 times. The solution was filtered into a round-bottomed flask using a 0.22 um filter. After concentration by a rotary evaporator to near $5 \mathrm{ml}$, the solution was concentrated to 1 $\mathrm{ml}$ by a high purity nitrogen gas stream. The extract was derivatized by BSTFA plus $1 \%$ TMCS at $70{ }^{\circ} \mathrm{C}$ for $2 \mathrm{~h}$, and used for analyzing the concentrations of $\mathrm{n}$-alkanoic acids and cholesterol (He et al., 2006; Schauer et al., 1999). The internal standard (hexamethylbenzene) was added to the samples. The last $1 / 4$ of the quartz filters was cut and put into a tube to analyze levoglucosan through a highperformance anion-exchange chromatography with pulsed amperometric detection (HPAEC-PAD) (Herisau, Switzerland) with a Hamilton RCX-30 250 column.

The other organic markers were analyzed by GC-MS (7890B/5977B, Agilent, USA) using a 30m $\times$ $0.25 \mathrm{~mm}$ diameter DB-5MS capillary column $(0.25 \mu \mathrm{m}$ film thickness). The carrier gas was pure helium (purity of $99.99 \%$ or more) at a constant flow rate of $1.0 \mathrm{~mL} \mathrm{~min}^{-1}$. For PAHs and hopanes, 
inlet and transfer line temperatures were set to $230^{\circ} \mathrm{C}$ and $280^{\circ} \mathrm{C}$ respectively. For n-alkane analysis, inlet and transfer line temperatures were set to $300^{\circ} \mathrm{C}$. EI mode was used and the ionization energy level was $70 \mathrm{eV}$.

Quality assurance and control were highly valued throughout the whole experiment. All samples and blank filters were analyzed using the same methods. Quartz filters were baked in an oven before use to remove organic interference. Before and after sampling, all the filters were equilibrated at the same environmental condition for $48 \mathrm{~h}$ in desiccators before weighing. Each filter was weighted by a sensitive microbalance with balance sensitivity $\pm 0.010 \mathrm{mg}$.

Field and laboratory blanks were measured to correct the corresponding data. The same procedure was used to analyze standards every day, including standards for each n-alkane, PAHs mixture, each hopane (O2Si Smart Solutions, USA); standards for PALMIA, STEARA, and CHOL (Dr. Ehrenstorfer, Germany); and standard for LEVOG (U.S. Pharmacopeia, USA). The recovery values of all target components showed a low relative standard deviation. In addition, the first sample of every ten samples was re-examined and the precision was found to be within $10 \%$. The recoveries were $79-106 \%$ for elements, and $96-110 \%$ for ions. For carbon fractions, a system stability test (threepeak detection) is required before and after detecting samples and the relative standard deviation should not exceed $5 \%$. The recoveries of most organic compounds ranged from $60 \%-130 \%$.

In addition, the chemical species were reconstructed using the following equations referred to in the IMPROVE Report V (Hand et al., 2011): 
Ammonium sulphate $=1.375\left[\mathrm{SO}_{4}{ }^{2-}\right]$

Ammonium nitrate $=1.29\left[\mathrm{NO}_{3}{ }^{-}\right]$

Organic matter $(\mathrm{OM})=1.8[\mathrm{OC}]$

Crustal material $=2.2[\mathrm{Al}]+2.49[\mathrm{Si}]+1.63[\mathrm{Ca}]+2.42[\mathrm{Fe}]+1.94[\mathrm{Ti}]$

Other $=$ PM-sulphate-nitrate-organic matter-crustal material-EC
(1)

\subsection{Chemical Mass Balance (CMB) Modelling}

The CMB model has been used extensively as a receptor model in air pollution source apportionment studies. The model is mainly based on two assumptions: 1) The measured chemical and physical properties must present in different proportions in different source emissions, and 2) the changes in these proportions are negligible or can be approximated during the process of particulate matter transport from the source to the receptor (Watson et al., 2002). Two methods were used to conduct the source apportionment of $\mathrm{PM}_{2.5}$. The organic marker-based CMB (OM-CMB) model was used in this study to apportion the sources of OC and $\mathrm{PM}_{2.5}$ (Schauer et al., 1996; Villalobos et al., 2017). This model was applied to determine the primary source contributions (including gasoline vehicles, diesel vehicles, industrial coal combustion, resuspended dust, biomass burning, cooking, and vegetation detritus) to $\mathrm{OC}$, and the contributions of the primary emission sources to $\mathrm{PM}_{2.5}$ were calculated using the ratios of $\mathrm{PM}_{2.5}$ mass to fine $\mathrm{OC}$ in each source. The $\mathrm{SO}_{4}{ }^{2-}$ and $\mathrm{NO}_{3}{ }^{-}$were not included in the OM-CMB modeling, but they were measured in the profiles of above primary sources, so the contributions of secondary $\mathrm{SO}_{4}{ }^{2-}$ and $\mathrm{NO}_{3}{ }^{-}$were calculated by the difference between the measured concentrations and the amount estimated in the primary source emissions (Zheng et al., 2002), and then they were converted to ammonium sulphate and ammonium nitrate using the equations (1) and (2) above. In addition, the secondary organic carbon (SOC) was considered as the 
unresolved source, and was calculated as the difference between measured OC and the sum of all significant contributions to OC (Villalobos et al., 2017).

For the inorganic and organic marker-based CMB (IOM-CMB) model, $\mathrm{PM}_{2.5}$ source apportionment was conducted based on inorganic and organic source profiles as showed in Table 1. The profiles of gasoline vehicles, diesel vehicles, industrial coal combustion, resuspended dust, biomass burning, cooking, soil dust, sulphate, and nitrate were inputted into the CMB model, and their contributions were directly obtained. The SOC was also calculated as the difference between measured OC and the sum of all primary contributions to OC, and then was converted to SOA through equation (3). The other difference from the OM-CMB is that the source profiles of vegetation detritus did not work in this calculation, and a soil dust profile was used. Although they are two different source categories, their profiles are similarly characterized by high loadings of C31 and C33 n-alkanes (Tian et al., 2021b) due to vegetation influence. Details of the source profiles used in the two methods will be discussed in Section 2.4. The components introduced into the OM-CMB and IOM-CMB are summarized in Table 1.

To ensure the reliability of the fitting results, the following parameters were used to evaluate the model outputs of the two methods. The percent mass explained by the model is typically between 80 and 120\%. For goodness-of-fit parameters, high $\mathrm{r}^{2}(>0.8)$ and low $\chi^{2}(<4)$ were required. In addition, the MPIN (modified pseudo inverse normalized) matrix was checked to determine the marker of each source category.

In addition, an independent estimation of the SOA was also conducted by the EC tracer method 
(defined as the $\mathrm{SOA}_{\mathrm{EC}}$ ) to compare with the SOA estimated the OM-CMB and IOM-CMB. Assuming EC totally comes from primary sources and the $\mathrm{OC} / \mathrm{EC}$ ratio in primary sources is relatively constant, SOCEC was estimated as in Turpin and Huntzicker (1995):

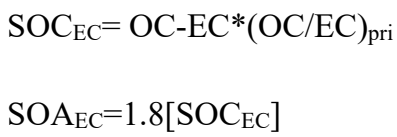

where $\mathrm{OC}$ and $\mathrm{EC}$ are the measured ambient concentrations; $(\mathrm{OC} / \mathrm{EC})_{\text {pri }}$ is the $\mathrm{OC} / \mathrm{EC}$ ratio in primary aerosols. (OC/EC) pri values of 2.0-2.2 are usually applied to identify and estimate SOA (Xu et al., 2021). In this study, the lowest $\mathrm{OC} / \mathrm{EC}$ ratio of all samples was observed as 2.0 , so $(\mathrm{OC} / \mathrm{EC})_{\mathrm{pri}}=2.0$ was used.

\subsection{Source Profiles}

The source profiles applied in this study include: (1) gasoline vehicles, diesel vehicles, coal combustion, resuspended dust and soil dust which were measured by ourselves (Tian et al., 2021b); (2) biomass burning (Wang et al., 2009; Pirovano et al., 2010), cooking (Zhao et al., 2015), and vegetative detritus (Rogge et al., 1993; Hildemann et al., 1991) from other publications; and (3) ammonium sulfate and ammonium nitrate which were used to represent secondary sulphate and nitrate. To test the sensitivity of CMB results to source profiles, two different profiles of coal combustion (residential vs. industrial coal combustion as in Tian et al., 2021b) and seven different profiles of gasoline vehicles (as in Tian et al. (2021b) vs. those from U.S. noncatalyst vehicles in Schauer et al. (2002) and from Chinese gasoline vehicles in Cai et al. (2017) were evaluated for CMB modelling. Inorganic ions and elements were not showed in the Cai et al. (2017), so only OM-CMB 
can be compared.

\section{RESULTS AND DISCUSSION}

\subsection{PM2.5 Chemical Composition}

The daily concentrations of the $\mathrm{PM}_{2.5}$ and mass closure of main species are shown in Figure 1a. $\mathrm{PM}_{2.5}$ concentrations ranged from 28 to $237 \mu \mathrm{g} \mathrm{m} \mathrm{m}^{-3}$. For the mass closure of $\mathrm{PM}_{2.5}$ chemical composition referred to the equations (1) to (5), the fractions were in the order of OM $(29 \%)>$ nitrate $(24 \%)>$ crustal material $(23 \%)>$ sulphate $(15 \%)>$ EC $(5 \%)$. The daily mass closures were generally consistent with the daily $\mathrm{PM}_{2.5}$ concentrations.

The daily concentrations of organic components are shown in Figure 1b to 1e. Their concentrations were in the order of $\sum 10$ n-alkanes $\left(99-393 \mathrm{ng} \mathrm{m}^{-3}\right)>$ levoglucosan $\left(16-894 \mathrm{ng} \mathrm{m}^{-3}\right)>\sum$ unsaturated fatty acids and cholesterol $\left(29-157 \mathrm{ng} \mathrm{m}^{-3}\right)>\sum_{14}$ PAHs $\left(1-96 \mathrm{ng} \mathrm{m}^{-3}\right)>\sum 3$ hopanes $\left(1-31 \mathrm{ng} \mathrm{m}^{-3}\right)$. The concentrations of n-alkanes, levoglucosan, PAHs and hopanes showed similar temporal variations with $\mathrm{PM}_{2.5}$ concentrations, while unsaturated fatty acids and cholesterol showed different variations.

\subsection{Source Contributions to $\mathrm{OC}$}

The annual average of the source contributions to OC estimated by the OM-CMB is shown in Figure 2a. The highest contributor for OC was SOC (34\%), followed by biomass burning (17\%), diesel vehicles (10\%), industrial coal combustion (9\%), gasoline vehicles $(8 \%)$, resuspended dust $(8 \%)$, vegetation detritus $(8 \%)$, and cooking $(6 \%)$. 
The daily percentage contributions to OC are shown in Figure 3a. The highest daily contributions to OC reached $6 \mu \mathrm{g} \mathrm{m}^{-3}$ for gasoline vehicles, $4 \mu \mathrm{g} \mathrm{m} \mathrm{m}^{-3}$ for diesel vehicles, $3 \mu \mathrm{g} \mathrm{m}^{-3}$ for industrial coal combustion, $4 \mu \mathrm{g} \mathrm{m}^{-3}$ for resuspended dust, $8 \mu \mathrm{g} \mathrm{m}^{-3}$ for biomass burning, $2 \mu \mathrm{g} \mathrm{m} \mathrm{m}^{-3}$ for cooking, $3 \mu \mathrm{g}$ $\mathrm{m}^{-3}$ for vegetation detritus, and $14 \mu \mathrm{g} \mathrm{m}^{-3}$ for SOC. The percentage contributions of gasoline vehicles were higher during January when the $\mathrm{PM}_{2.5}$ concentrations were the highest (due to a heavy pollution episode). The percentage contributions of industrial coal combustion were higher during the dry season. The biomass burning showed higher fractions during autumn and winter. The high vegetation detritus concentrations were mainly observed during spring (April). The higher SOA fractions were observed during August to October when photochemistry is most active and primary emissions of some components are lower. The contributions of diesel vehicles, resuspended dust, and cooking showed no obvious seasonal variation.

\subsection{Source Contributions to $\mathbf{P M}_{2.5}$}

As described in the methods section, for the OM-CMB model, the source contributions to $\mathrm{PM}_{2.5}$ were converted from the contributions to OC. The average source contributions and conversion ratios are summarized in Table S1. For the IOM-CMB model, the source contributions to $\mathrm{PM}_{2.5}$ were directly estimated. Figures $2 \mathrm{~b}$ and $2 \mathrm{c}$ describe the annual average source contributions to $\mathrm{PM}_{2.5}$. The percentage contributions of gasoline vehicles, diesel vehicles, industrial coal combustion, resuspended dust, biomass burning, cooking, vegetation detritus, SOA, sulphate, and nitrate were 4\%, $10 \%, 15 \%, 12 \%, 5 \%, 3 \%, 4 \%, 9 \%, 10 \%$, and $20 \%$ for $\mathrm{OM}-\mathrm{CMB}$, and $4 \%, 11 \%, 15 \%, 17 \%, 6 \%, 2 \%$, $5 \%, 10 \%, 7 \%$, and $18 \%$ for IOM-CMB.

The daily percentage contributions to $\mathrm{PM}_{2.5}$ estimated by the two methods are shown in Figures $3 \mathrm{~b}$ 
and $3 \mathrm{c}$, and the absolute contributions are shown in Figure 4. The highest daily contributions to $\mathrm{PM}_{2.5}$ reached 21 and $20 \mu \mathrm{g} \mathrm{m}^{-3}$ for gasoline vehicles, 28 and $24 \mu \mathrm{g} \mathrm{m}^{-3}$ for diesel vehicles, 33 and $39 \mu \mathrm{g} \mathrm{m}^{-}$

${ }^{3}$ for industrial coal combustion, 34 and $34 \mu \mathrm{g} \mathrm{m}^{-3}$ for resuspended dust, 17 and $17 \mu \mathrm{g} \mathrm{m}{ }^{-3}$ for biomass burning, 6 and $6 \mu \mathrm{g} \mathrm{m}^{-3}$ for cooking, 8 and $8 \mu \mathrm{g} \mathrm{m}^{-3}$ for vegetation detritus, 26 and $25 \mu \mathrm{g} \mathrm{m}^{-3}$ for SOA, 28 and $21 \mu \mathrm{g} \mathrm{m}^{-3}$ for sulphate, and 75 and $66 \mu \mathrm{g} \mathrm{m}^{-3}$ for nitrate, estimated by the OM-CMB and IOMCMB models, respectively.

As shown in Figure $3 b, 3 c$ and 4, the temporal variations of source contributions to $\mathrm{PM}_{2.5}$ were similar to those to OC. The gasoline vehicles showed obvious higher contributions during the cold period. Studies have shown that gasoline vehicles emit more PM under poor combustion conditions, such as cold starts at low temperature (Schauer et al., 1999 and 2003). The percentage contributions of industrial coal combustion were higher during the dry season. Hydropower supplies a large percentage of Chengdu's electricity demand during the wet season, while coal combustion is needed for electricity generation during the dry season (Shi et al., 2016). Biomass burning showed higher fractions during autumn and winter, due to residential use and local straw burning activities. A high vegetation detritus/soil dust contribution was mainly observed during spring, while the resuspended dust showed weaker seasonal variations. The vegetation detritus and soil dust are natural sources, and their contributions are associated respectively with vegetation and meteorological condition. The resuspended dust can be caused by high wind strength and intensive human activities (such as road dust caused by heavy traffic, construction dust caused by building activities, etc.).

The highest percentage contributions of SOA and sulphate were observed during August to October. Their formation is associated with photochemical processes which are more efficient because of 
strong illumination, less precipitation and high temperature during August to October. The SOA and sulphate also showed higher contributions during January. Although photochemical reactions may be generally weak during January, high precursor concentrations, humidity and PM during winter may enhance the aqueous phase and heterogeneous reactions. The highest fraction of nitrate occurred when the temperature was low (as shown in Figure 1). Although photochemical reactions are favourable in summer, nitrate may decompose at higher temperatures due to the thermodynamic instability of ammonium nitrate (Hasheminassab et al., 2014), and the high relative humidity during wintertime in Chengdu can enhance the secondary formation of nitrate through heterogeneous reactions (Liu et al., 2019).

\subsection{Comparisons of Daily Source Contributions and markers}

In this study, except for the soil dust and vegetation detritus, similar source categories were shared by the OM-CMB and IOM-CMB. Thus, a comparison of the contributions estimated by the two CMB methods was conducted. Furthermore, the contributions were also compared with the corresponding markers which had high MPIN values. The temporal variations of source contributions and corresponding markers which had high MPIN were compared, as shown in Figure 4.

\section{It can be seen that the average contributions of sulphate and nitrate from the OM-CMB were higher} than those from the IOM-CMB (as shown in Figure 2), while their daily contributions were highly consistent with each other and with the trends of corresponding markers. The sulfate and nitrate sources from the OM-CMB are the measured values after subtracting the summed mass of sulfate and nitrate emitted from the selected primary sources as described in the section 2.3 , while those from the

IOM-CMB were directly estimated by the CMB model. The consistent temporal variations of 
contributions indicate they were well estimated by the two methods due to the low collinearity. The difference of average contributions might be caused by uncertainties in the estimation of primary source contributions (such as in resuspended dust), if the actual source compositions differs from the profiles used in the model. As shown in Figure 4, the average values and temporal variations of the SOA from two methods were also in agreement with each other, and with the $\mathrm{SOA} \mathrm{EC}_{\mathrm{EC}}$ which was independently estimated by the EC tracer method according to equations (6) to (7). The SOA estimated by the IOM-CMB was more consistent with the $\mathrm{SOA}_{\min }$ than that estimated by the OMCMB, because EC was used in the IOM-CMB.

According to Figure 2, among the primary source categories, the average contributions of the gasoline vehicles, diesel vehicles, industrial coal combustion and cooking estimated by the two methods were generally consistent, and the average contributions of resuspended dust and dust/vegetation detritus showed larger differences for the two methods. What's more, as shown in Figure 4, the daily variability of biomass burning and gasoline vehicles from two methods showed more consistent temporal variations (with squared correlation coefficient $\mathrm{R}^{2}=0.87$ and 0.86 ) than other primary sources (with $\mathrm{R}^{2}$ ranged from 0.53 to 0.67 ). The biomass burning and gasoline vehicle contributions also showed similar temporal variations with their corresponding markers. The marker of gasoline vehicles was BghiP and the marker of biomass burning was LEVOG, which were very different from other sources, so their low collinearity with other sources can explain the consistent results. The daily contributions of diesel vehicles and industrial coal combustion of the two methods were moderately consistent. Consistent markers were identified for these two sources by the OM-CMB and IOM-CMB; however, the collinearity between source profiles of diesel vehicles and industrial coal combustion may cause some differences. For example, they are both characterized by high loadings of C24, C25 
alkanes and medium-ring PAHs (Tian et al., 2021b). The contributions of resuspended dust estimated by the two methods showed differences, probably because different markers (C31 for OM-CMB and Ca for IOM-CMB) were identified for $\mathrm{CMB}$ modeling. Cooking contributions estimated by the two methods also showed weak correlations with each other and with the corresponding marker, which may be due to its contributions being generally low and influenced by other source categories. The STEARA also exists in the source profiles of other sources, so the differences of other source contributions can influence its attribution and the cooking contribution.

\subsection{Sensitivity of Source Apportionment to Source Profiles}

Two different profiles for two major sources - coal combustion and gasoline vehicles - were used to test the sensitivity to source profiles as mentioned above. The result of the IOM-CMB which used the residential coal combustion instead of industrial coal combustion profile is shown in Figure S1. Compared with the result for the industrial coal combustion, the contributions of resuspended dust and residential coal combustion were higher, and the contributions of other sources were lower. The difference between two coal combustion profiles was that the residential coal combustion showed higher OC and organic compounds and lower crustal elements than the industrial coal combustion (Tian et al., 2021b). The lower crustal elements in the residential coal combustion may explain the overestimation of the resuspended dust, whose markers were mainly crustal elements, when using its profile. Residential coal combustion is an important source category in northern China, but there is little in the central city of southern China. Thus, the industrial coal combustion source profile was selected in this study.

For the gasoline vehicle profiles, most results did not meet the goodness-of-fit criteria when using the 
noncatalyst vehicle profile measured by Schauer et al. (2002). Figure S2 describes the OC-CMB results using the Chinese gasoline vehicle profiles measured by Cai et al. (2017). Except for the heavy gasoline 2, most results were comparable with the results using our gasoline vehicle profiles. In summary, it is important to use local and up-to-date source profiles for the source apportionment, and to include more components in the profiles.

\section{CONCLUSIONS}

To explore the influence of introducing inorganic markers and sensitivity to source profiles, a comprehensive comparison of $\mathrm{PM}_{2.5}$ source apportionment using organic marker-based OM-CMB as well as organic and inorganic marker-based IOM-CMB was conducted. The percentage contributions of gasoline vehicles, diesel vehicles, industrial coal combustion, resuspended dust, biomass burning, cooking, vegetation detritus, SOA, sulphate, and nitrate were $4 \%, 10 \%, 15 \%, 12 \%, 5 \%, 3 \%, 4 \%, 9 \%$, $10 \%$, and $20 \%$ for OM-CMB, and $4 \%, 11 \%, 15 \%, 17 \%, 6 \%, 2 \%, 5 \%, 10 \%, 7 \%$, and $18 \%$ for IOMCMB. The temporal variations of $\mathrm{PM}_{2.5}$ contributions from sulphate, nitrate, SOA, gasoline vehicles, and biomass burning were in good agreement between the OM-CMB and IOM-CMB results. The OM-CMB and IOM-CMB are powerful to apportion sources characterized by unique markers (such as biomass combustion) and low collinearity. The diesel vehicle and industrial coal combustion estimates were moderately consistent between the two methods. The OM-CMB resuspended dust and cooking estimates showed poor correlation with the IOM-CMB results. The discrepancy in resuspended dust between OM-CMB and IOM-CMB may be due to the different tracers in their source profiles. In addition, when testing the sensitivity to source profiles for two coal combustion and two gasoline vehicle profiles, it was found important to use current and relevant source profiles according to local source information for the source apportionment. 


\section{DATA ACCESSIBILITY}

Data supporting this publication are openly available from the UBIRA eData repository at (https://doi.org/10.25500/edata.bham.00000745

\section{AUTHOR CONTRIBUTIONS}

YZ and RMH conceived the study. YZ, RMH, and ZS guided the work and wrote the paper. XW and PZ carried out the chemical analysis and data analysis.

\section{COMPETING INTERESTS}

The authors declare that they have no conflict of interest.

\section{FINANCIAL SUPPORT}

This research has been supported by the National Natural Science Foundation of China (41977181), and Young Elite Scientists Sponsorship Program by Tianjin, China (TJSQNTJ-2018-04). RMH and ZS are supported by Natural Environment Research Council (NE/N007190/1). 


\section{REFERENCE}

Arhami, M., Shahne, M. Z., Hosseini, V., Haghighat, N. R., Lai, A. M., and Schauer, J. J.: Seasonal trends in the composition and sources of $\mathrm{PM}_{2.5}$ and carbonaceous aerosol in Tehran, Iran, Environ. Pollut., 239, 69-81, https://doi.org/10.1016/j.envpol.2018.03.111, 2018.

Bell, M. L., Ebisu, K., Leaderer, B. P., Gent, J. F., Lee, H. J., Koutrakis, P., Wang, Y., and Dominici, F., Peng, R. D.: Associations of $\mathrm{PM}_{2.5}$ constituents and sources with hospital admissions: Analysis of four counties in Connecticut and Massachusetts (USA) for persons $>=65$ years of age, Environ. Health. Perspect., 122, 138-144, https://doi.org/10.1289/ehp.1306656, 2014.

Cai, T., Zhang, Y., Fang, D., Shang, J., Zhang, Y., and Zhang, Y.: Chinese vehicle emissions characteristic testing with small sample size: Results and comparison, Atmos. Pollut. Res., 8, 154163, https://doi.org/10.1016/j.apr.2016.08.007, 2017.

Cao, F., Zhang, Y. X., Lin, X., and Zhang, Y. L.: Characteristics and source apportionment of nonpolar organic compounds in $\mathrm{PM}_{2.5}$ from the three megacities in Yangtze River Delta region, China, Atmos. Res., 252, 105443, https://doi.org/10.1016/j.atmosres.2020.105443, 2021.

Chen, P. L., Wang, T. J., Hu, X., and Xie, M.: Chemical mass balance source apportionment of sizefractionated particulate matter in Nanjing, China, Aerosol Air Qual. Res., 15, 1855-1867, https://doi.org/10.4209/aaqr.2015.03.0172, 2015.

Chow, J. C., Watson, J. G., Lowenthal, D. H., Chen, L. W. A., Zielinska, B., Mazzoleni, L. R., and Magliano, K. L.: Evaluation of organic markers for chemical mass balance source apportionment at the Fresno Supersite, Atmos. Chem. Phys., 7, 1741-1754, https://doi.org/10.5194/acp-7-1741-2007, 2007.

Clappier, A., Pisoni, E., and Thunis, P.: A new approach to design source-receptor relationships for air quality modelling, Environ. Model. Softw., 74, 66-74, https://doi.org/10.1016/j.envsoft.2015.09.007, 2015.

Esmaeilirad, S., Lai, A., Abbaszade, G., Schnelle-Kreis, J., Zimmermann, R., Uzu, G., Daellenbach, K., Canonaco, F., Hassankhany, H., Arhami, M., Baltensperger, U., Prevot, A. S. H., Schauer, J. J., Jaffrezo, J. L., Hosseini, V., and El Haddad, I.: Source apportionment of fine particulate matter in a Middle Eastern Metropolis, Tehran-Iran, using PMF with organic and inorganic markers, Sci. Tot. Environ., 705, 135330, https://doi.org/10.1016/j.scitotenv.2019.135330, 2020.

Guan, P., Wang, X., Cheng, S., and Zhang, H.: Temporal and spatial characteristics of $\mathrm{PM}_{2.5}$ transport fluxes of typical inland and coastal cities in China, J. Environ. Sci., 103, 229-245, https://doi.org/10.1016/j.jes.2020.10.017, 2021.

Guo, S., Hu, M., Guo, Q., Zhang, X., Schauer, J. J., and Zhang, R.: Quantitative evaluation of emission controls on primary and secondary organic aerosol sources during Beijing 2008 Olympics, Atmos. Chem. Phys., 13, 8303-8314, https://doi.org/10.5194/acp-13-8303-2013, 2013. 
Hand, J., Copeland, S., McDade, C., Day, D., Moore Jr., C., Dillner, A., Pitchford, M., Indresand, H., Schichtel, B., Malm, W., Watson, J.: Interagency monitoring of protected visual environments (IMPROVE). In: Spatial and Seasonal Patterns and Temporal Variability of Haze and its Constituents in the United States. Report V ISSN: 0737-5352-87, 2011.

Hasheminassab, S., Daher, N., Saffari, A., Wang, D., Ostro, B.D., and Sioutas, C.: Spatial and temporal variability of sources of ambient fine particulate matter $\left(\mathrm{PM}_{2.5}\right)$ in California, Atmos. Chem. Phys., 14, 12085-12097, https://doi.org/10.5194/acp-14-12085-2014, 2014.

He, L. Y., Hu, M., Huang, X. F., Zhang, Y. H., and Tang, X. Y.: Seasonal pollution characteristics of organic compounds in atmospheric fine particles in Beijing, Sci. Tot. Environ., 359, 167-176, https://doi.org/10.1016/j.scitotenv.2005.05.044, 2006.

Hildemann, L. M., Markowski, G. R., and Cass, G. R.: Chemical composition of emissions from urban sources of fine organic aerosol, Environ. Sci. Technol., 25, 744-759, https://doi.org/10.1021/es00016a021, 1991.

Hong, Y., Xu, X., Liao, D., Ji, X., Hong, Z., Chen, Y., Xu, L., Li, M., Wang, H., Zhang, H., Xiao, H., Choi, S.-D., and Chen, J.: Air pollution increases human health risks of $\mathrm{PM}_{2.5}$-bound PAHs and nitro-PAHs in the Yangtze River Delta, China, Sci. Tot. Environ., 770, 145402, https://doi.org/10.1016/j.scitotenv.2021.145402, 2021.

Ke, L., Liu, W., Wang, Y., Russell, A. G., Edgerton, E. S., and Zheng, M.: Comparison of PM2.5 source apportionment using positive matrix factorization and molecular marker-based chemical mass balance, Sci. Tot. Environ., 394, 290-302, https://doi.org/10.1016/j.scitotenv.2008.01.030, 2008.

Li, X., Yan, C., Wang, C., Ma, J., Li, W., Liu, J., and Liu, Y.: PM2.5-bound elements in Hebei Province, China: Pollution levels, source apportionment and health risks, Sci. Tot. Environ., 806, 150440, https://doi.org/10.1016/j.scitotenv.2021.150440, 2022.

Li, F. X., Gu, J. W., Xin, J. Y., Schnelle-Kreis, J., Wang, Y. S., Liu, Z. R., Shen, R. R., Michalke, B., Abbaszade, G., and Zimmermann, R.: Characteristics of chemical profile, sources and PAH toxicity of $\mathrm{PM}_{2.5}$ in Beijing in autumn-winter transit season with regard to domestic heating, pollution control measures and meteorology, Chemosphere, 276, 130143, https://doi.org/10.1016/j.chemosphere.2021.130143, 2021.

Li, L., Li, Q., Huang, L., Wang, Q., Zhu, A. S., Xu, J., Liu, Z. Y., Li, H. L., Shi, L. S., Li, R., Azari, M., Wang, Y. J., Zhang, X. J., Liu, Z. Q., Zhu, Y. H., Zhang, K., Xue, S. H., Ooi, M. C. G., Zhang, D. P., and Chan, A.: Air quality changes during the COVID-19 lockdown over the Yangtze River Delta Region: An insight into the impact of human activity pattern changes on air pollution variation, Sci. Tot. Environ., 732, 139282, https://doi.org/10.1016/j.scitotenv.2020.139282, 2020a.

Li, J. J., Li, J., Wang, G. H., Zhang, T., Dai, W. T., Ho, K. F., Wang, Q. Y., Shao, Y., Wu, C., and Li, L.: Molecular characteristics of organic compositions in fresh and aged biomass burning aerosols, 
Sci. Tot. Environ., 741, 140247, https://doi.org/10.1016/j.scitotenv.2020.140247, 2020b.

Li, R., Wang, Q. Q., He, X., Zhu, S. H., Zhang, K., Duan, Y. S., Fu, Q. Y., Qiao, L. P., Wang, Y. J., Huang, L., Li, L., and Yu, J. Z.: Source apportionment of $\mathrm{PM}_{2.5}$ in Shanghai based on hourly organic molecular markers and other source tracers, Atmos. Chem. Phys., 20, 12047-12061, https://doi.org/10.5194/acp-20-12047-2020, 2020c.

Liu, F., Tan, Q., Jiang, X., Yang, F., and Jiang, W.: Effects of relative humidity and $\mathrm{PM}_{2.5}$ chemical compositions on visibility impairment in Chengdu, China, J. Environ. Sci., 86, 15-23, https://doi.org/ 10.1016/j.jes.2019.05.004, 2019.

Liu, Q. Y., Baumgartner, J., Zhang, Y., and Schauer, J. J.: Source apportionment of Beijing air pollution during a severe winter haze event and associated pro-inflammatory responses in lung epithelial cells, Atmos. Environ., 126, 28-35, https://doi.org/10.1016/j.atmosenv.2015.11.031, 2016.

Lu, Z. J., Liu, Q. Y., Xiong, Y., Huang, F., Zhou, J. B., and Schauer, J. J.: A hybrid source apportionment strategy using positive matrix factorization (PMF) and molecular marker chemical mass balance (MM-CMB) model, Environ. Pollut., 238, 39-51, https://doi.org/10.1016/j.envpol.2018.02.091, 2018.

Mancilla, Y., Medina, G., Gonzalez, L. T., Herckes, P., Fraser, M. P., and Mendoza, A.: Determination and similarity analysis of $\mathrm{PM}_{2.5}$ emission source profiles based on organic markers for Monterrey, Mexico, Atmosphere, 12, 554, https://doi.org/10.3390/atmos12050554, 2021.

Marmur, A., Park, S. K., Mulholland, J. A., Tolbert, P. E., and Russell, A. G.: Source apportionment of $\mathrm{PM}_{2.5}$ in the southeastern United States using receptor and emissions-based models: Conceptual differences and implications for time-series health studies, Atmos. Environ., 40, 2533-2551, https://doi.org/10.1016/j.atmosenv.2005.12.019, 2006.

Mor, S., Kumar, S., Singh, T., Dogra, S., Pandey, V., and Ravindra, K.: Impact of COVID-19 lockdown on air quality in Chandigarh, India: Understanding the emission sources during controlled anthropogenic activities, Chemosphere, 263, 127978, https://doi.org/10.1016/j.chemosphere.2020.127978, 2021.

Olson, D. A., Turlington, J., Duvall, R. V., Vicdow, S. R., Stevens, C. D., and Williams, R.: Indoor and outdoor concentrations of organic and inorganic molecular markers: Source apportionment of PM2.5 using low-volume samples, Atmos. Environ., 42, 1742-1751, https://doi.org/10.1016/j.atmosenv.2007.11.035, 2008.

Perrone, M. G., Larsen, B. R., Ferrero, L., Sangiorgi, G., De Gennaro, G., Udisti, R., Zangrando, R., Gambaro, A., and Bolzacchini, E.: Sources of high $\mathrm{PM}_{2.5}$ concentrations in Milan, Northern Italy: Molecular marker data and CMB modelling, Sci. Tot. Environ., 414, 343-355, https://doi.org/10.1016/j.scitotenv.2011.11.026, 2012. 
Pirovano, G., Colombi, C., Balzarini, A., Riva, G. M., Gianelle, V., and Lonati, G.: PM2.5 source apportionment in Lombardy (Italy): Comparison of receptor and chemistry-transport modelling results, Atmos. Environ., 106, 56-70, https://doi.org/10.1016/j.atmosenv.2015.01.073, 2015.

Robinson, A. L., Subramanian, R., Donahue, N. M., Bernardo-Bricker, A., and Rogge, W. F.: Source apportionment of molecular markers and organic aerosol. 3. Food cooking emissions, Environ. Sci. Technol., 40, 7820-7827, https://doi.org/ 10.1021/es060781p, 2006.

Rogge, W. F., Hildemann, L. M., Mazurek, M. A., Cass, G. R., and Simoneit, B.: Sources of fine organic aerosol. 4. Particulate abrasion products from leaf surfaces of urban plants, Environ. Sci. Technol., 27, 2700-2711, https://doi.org/10.1021/es00049a008, 1993.

Schauer, J. J.: Evaluation of elemental carbon as a marker for diesel particulate matter, J. Expo. Anal. Env. Epid., 13, 443-453, https://doi.org/10.1038/sj.jea.7500298, 2003.

Schauer, J. J., Kleeman, M. J., Cass, G. R., and Simoneit, B. R. T.: Measurement of emissions from air pollution sources. 5. C-1-C-32 organic compounds from gasoline-powered motor vehicles, Environ. Sci. Technol., 36, 1169-1180, https://doi.org/ 10.1021/es0108077, 2002.

Schauer, J. J., and Cass, G. R.: Source apportionment of wintertime gas-phase and particle-phase air pollutants using organic compounds as tracers, Environ. Sci. Technol., 34, 1821-1832, https://doi.org/10.1021/es981312t, 2000.

Schauer, J. J., Kleeman, M. J., Cass, G. R., and Simoneit, B. R. T.: Measurement of emissions from air pollution sources. 1. C-1 through C-29 organic compounds from meat charbroiling, Environ. Sci. Technol., 33, 1566-1577, https://doi.org/10.1021/es980076j, 1999.

Schauer, J. J., Rogge, W.F ., Hildemann, L. M., Mazurek, M. A., and Cass, G. R.: Source apportionment of airborne particulate matter using organic compounds as tracers, Atmos. Environ., 30, 3837-3855, https://doi.org/10.1016/1352-2310(96)00085-4, 1996.

Shi, G. L., Peng, X., Liu, J. Y., Tian, Y. Z., Song, D. L., Yu, H. F., Feng, Y. C., and Russell, A. G.: Quantification of long-term primary and secondary source contributions to carbonaceous aerosols, Environ. Pollut., 219, 897-905, https://doi.org/10.1016/j.envpol.2016.09.009, 2016.

Song, L., Dai, Q., Feng, Y., and Hopke, P. K.: Estimating uncertainties of source contributions to $\mathrm{PM}_{2.5}$ using moving window evolving dispersion normalized PMF, Environ. Pollut., 286, 117576, https://doi.org/10.1016/j.envpol.2021.117576, 2021.

Tian, Y. Z., Harrison, R. M., Feng, Y. C., Shi, Z. B., Liang, Y. L., Li, Y. X., Xue, Q. Q., and Xu, J. S.: Size-resolved source apportionment of particulate matter from a megacity in northern China based on one-year measurement of inorganic and organic components, Environ. Pollut., 289, 117932, https://doi.org/10.1016/j.envpol.2021.117932, 2021a.

Tian, Y. Z., Liu, X., Huo, R. Q., Shi, Z. B., Sun, Y. M., Feng, Y. C., and Harrison, R. M.: Organic 
compound source profiles of $\mathrm{PM}_{2.5}$ from traffic emissions, coal combustion, industrial processes and dust, Chemosphere, 278, 130429, https://doi.org/10.1016/j.chemosphere.2021.130429, 2021 b.

Tian, Y. Z., Shi, G. L., Han, S. Q., Zhang, Y. F., Feng, Y. C., Liu, G. R., Gao, L. J., Wu, J. H., and Zhu, T.: Vertical characteristics of levels and potential sources of water-soluble ions in $\mathrm{PM}_{10}$ in a Chinese megacity, Sci. Tot. Environ., 447, 1-9, https://doi.org/10.1016/j.scitotenv.2012.12.071, 2013.

Turpin, B. J., and Huntzicker, J. J.: Identification of secondary organic aerosol episodes and quantitation of primary and secondary organic aerosol concentrations during SCAQS, Atmos. Environ., 29, 3527-3544, https://doi.org/10.1016/1352-2310(94)00276-Q, 1995.

Villalobos, A. M., Barraza, F., Jorquera, H., and Schauer, J. J.: Wood burning pollution in southern Chile: $\mathrm{PM}_{2.5}$ source apportionment using CMB and molecular markers, Environ. Pollut., 225, 514523, https://doi.org/10.1016/j.envpol.2017.02.069, 2017.

Wang, J., Hu, Z. M., Chen, Y.Y ., Chen, Z. L., and Xu, S. Y.: Contamination characteristics and possible sources of $\mathrm{PM}_{10}$ and $\mathrm{PM}_{2.5}$ in different functional areas of Shanghai, China, Atmos. Environ., 68, 221-229, https://doi.org/10.1016/j.atmosenv.2012.10.070, 2013.

Wang, Q., Shao, M., Zhang, Y., Wei, Y., Hu, M., and Guo, S.: Source apportionment of fine organic aerosols in Beijing, Atmos. Chem. Phys., 9, 9043-9080, https://doi.org/10.5194/acp-9-8573-2009, 2009.

Watson, J. G., Zhu, T., Chow, J. C., Engelbrecht, J., Fujita, E. M., and Wilson, W. E.: Receptor modeling application framework for particle source apportionment, Chemosphere, 49, 1093-1136, https://doi.org/10.1016/S0045-6535(02)00243-6, 2002.

Wen, J., Chuai, X., Gao, R., and Pang, B.: Regional interaction of lung cancer incidence influenced by PM2.5 in China, Sci. Tot. Environ., 803, 149979,

https://doi.org/10.1016/j.scitotenv.2021.149979, 2022.

Wong, Y. K., Huang, X. H. H., Cheng, Y. Y., and Yu, J. Z.: Estimating primary vehicular emission contributions to $\mathrm{PM}_{2.5}$ using the Chemical Mass Balance model: Accounting for gas-particle partitioning of organic aerosols and oxidation degradation of hopanes, Environ. Pollut., 291, 118131, https://doi.org/10.1016/j.envpol.2021.118131, 2021.

Wu, X. F., Chen, C. R., Vu, T. V., Liu, D., Baldo, C., Shen, X. B., Zhang, Q., Cen, K., Zheng, M., He, K. B., Shi, Z. B., and Harrison, R. M.: Source apportionment of fine organic carbon (OC) using receptor modelling at a rural site of Beijing: Insight into seasonal and diurnal variation of source contributions, Environ. Pollut., 266, 115078, https://doi.org/10.1016/j.envpol.2020.115078, 2020.

Xu, J. S., Liu, D., Wu, X. F., Vu, T., Zhang, Y. L., Fu, P. Q., Sun, Y. L., Xu, W. Q., Zheng, B., Harrison, R. M., and Shi, Z. B.: Source apportionment of fine organic carbon at an urban site of Beijing using a chemical mass balance model, Atmos. Chem. Phys., 21, 7321-7341, 
https://doi.org/10.5194/acp-21-7321-2021, 2021.

Yang, Y., Ruan, Z., Wang, X., Yang, Y., Mason, T. G., Lin, H., and Tian, L.: Short-term and longterm exposures to fine particulate matter constituents and health: A systematic review and metaanalysis, Environ. Pollut., 247, 874-882, https://doi.org/10.1016/j.envpol.2018.12.060, 2019.

Yin, J., Cumberland, S. A., Harrison, R. M., Allan, J., Young, D. E., Williams, P. I., and Coe, H.: Receptor modelling of fine particles in southern England using CMB including comparison with AMS-PMF factors, Atmos. Chem. Phys., 15, 2139-2158, doi:10.5194/acp-15-2139-2015, 2015.

Zhan, J. L., Feng, Z. M., Liu, P. F., He, X. W., He, Z. M., Chen, T. Z., Wang, Y. F., He, H., Mu, Y. J., and Liu, Y. C.: Ozone and SOA formation potential based on photochemical loss of VOCs during the Beijing summer, Environ. Pollut., 285, 117444, https://doi.org/10.1016/j.envpol.2021.117444, 2021.

Zhang, C., Jing, D., Wu, C., Li, S., Cheng, N., Li, W., Wang, G., Chen, B., Wang, Q., and Hu, J.: Integrating chemical mass balance and the community multiscale air quality models for source identification and apportionment of $\mathrm{PM}_{2.5}$, Process. Saf. Environ., 149, 665-675, https://doi.org/10.1016/j.psep.2021.03.033, 2021a.

Zhang, D., He, B., Yuan, M. H., Yu, S. J., Yin, S. S., and Zhang, R. Q.: Characteristics, sources and health risks assessment of VOCs in Zhengzhou, China during haze pollution season, J. Environ. Sci., 108, 44-57, https://doi.org/10.1016/j.jes.2021.01.035, 2021b.

Zhang, Y. L., Zhu, B., Gao, J. H., Kang, H. Q., Yang, P., Wang, L. L., and Zhang, J. K.: The source apportionment of primary $\mathrm{PM}_{2.5}$ in an aerosol pollution event over Beijing-Tianjin-Hebei region using WRF-Chem, China, Aerosol Air Qual. Res., 17, 2966-2980, https://doi.org/10.4209/aaqr.2016.10.0442, 2017.

Zhang, R., Jing, J., Tao, J., Hsu, S.C., Wang, G., Cao, J., Lee, C. S. L., Zhu, L., Chen, Z., Zhao, Y., and Shen, Z.: Chemical characterization and source apportionment of $\mathrm{PM}_{2.5}$ in Beijing: Seasonal perspective, Atmos. Chem. Phys., 13, 7053-7074, https://doi.org/10.5194/acp-13-7053-2013, 2013.

Zhao, X. Y., Hu, Q. H., Wang, X. M., Ding, X., He, Q. F., Zhang, Z., Shen, R. Q., Lu, S. J., Liu, T. Y., Fu, X. X., and Chen, L. G.: Composition profiles of organic aerosols from Chinese residential cooking: case study in urban Guangzhou, south China, J. Atmos. Chem., 72, 1-18, https://doi.org/10.1007/s10874-015-9298-0, 2015.

Zhao, P. S., Dong, F., He, D., Zhao, X. J., Zhang, X. L., Zhang, W. Z., Yao, Q., and Liu, H. Y.: Characteristics of concentrations and chemical compositions for $\mathrm{PM}_{2.5}$ in the region of Beijing, Tianjin, and Hebei, China, Atmos. Chem. Phys., 13, 4631-4644, https://doi.org/10.5194/acp-134631-2013, 2013.

Zheng, M., Salmon, L. G., Schauer, J. J., Zeng, L. M., Kiang, C. S., Zhang, Y. H., and Cass, G. R.: Seasonal trends in $\mathrm{PM}_{2.5}$ source contributions in Beijing, China, Atmos. Environ., 39, 3967-3976, 
https://doi.org/10.5194/acp-2021-1007

Preprint. Discussion started: 8 February 2022

(C) Author(s) 2022. CC BY 4.0 License.

697 https://doi.org/10.1016/j.atmosenv.2005.03.036, 2005.

698

699 Zheng, M., Cass, G. R., Schauer, J. J., and Edgerton, E. S.: Source apportionment of PM 2.5 in the

700 Southeastern United States using solvent-extractable organic compounds as tracers, Environ. Sci.

701 Technol., 36, 2361, https://doi.org/10.1021/es011275x, 2002.

702

703 


\section{TABLE CAPTION}

Table 1: Full names and abbreviations of the components used in the OM-CMB and IOM-CMB.

\section{FIGURE CAPTIONS}

Figure 1: The daily concentrations of $\mathrm{PM}_{2.5}$, mass closure of main species, and organic components. (a) Mass closure of main species; (b) n-alkanes; (c) PAHs; (d) hopanes; (e) unsaturated fatty acids and cholesterol.

Figure 2: (a) The average of percentage contributions to OC estimated by the OM-CMB; (b) The annual average of percentage contributions to $\mathrm{PM}_{2.5}$ estimated by the OM-CMB; (c) The annual average of percentage contributions to $\mathrm{PM}_{2.5}$ estimated by the IOM-CMB; (d) Comparison of contributions to $\mathrm{PM}_{2.5}$ estimated by the OM-CMB and IOM-CMB.

Figure 3: (a) Daily contributions to OC estimated by the OM-CMB; (b) Daily contributions to $\mathrm{PM}_{2.5}$ estimated by the OM-CMB; (c) Daily contributions to $\mathrm{PM}_{2.5}$ estimated by the IOM-CMB.

Figure 4: Comparisons among source contributions estimated by the OM-CMB and IOM-CMB, and corresponding markers. 
https://doi.org/10.5194/acp-2021-1007

Preprint. Discussion started: 8 February 2022

(c) Author(s) 2022. CC BY 4.0 License.

Table 1. Full names and abbreviations of the components used in the OM-CMB and IOM-CMB.

\begin{tabular}{|c|c|c|c|}
\hline Components & Abbreviations & Used in OM-CMB & Used in IOM-CMB \\
\hline organic carbon & $\mathrm{OC}$ & & Yes \\
\hline element carbon & $\mathrm{EC}$ & & Yes \\
\hline ammonium & $\mathrm{NH}_{4}^{+}$ & & Yes \\
\hline chloride & $\mathrm{Cl}^{-}$ & & Yes \\
\hline nitrate & $\mathrm{NO}_{3}^{-}$ & & Yes \\
\hline sulfate & $\mathrm{SO}_{4}{ }^{2-}$ & & Yes \\
\hline aluminum & $\mathrm{Al}$ & & Yes \\
\hline silicon & $\mathrm{Si}$ & & Yes \\
\hline calcium & $\mathrm{Ca}$ & & Yes \\
\hline polycyclic aromatic hydrocarbons & PAHs & & \\
\hline phenanthrene & Phe & Yes & Yes \\
\hline anthracene & Ant & Yes & Yes \\
\hline fluoranthene & Flt & Yes & Yes \\
\hline pyrene & Pyr & Yes & Yes \\
\hline benz(a)anthracene & $\mathrm{BaA}$ & Yes & Yes \\
\hline chrysene & $\mathrm{Chr}$ & Yes & Yes \\
\hline benzo(b)fluoranthene & $\mathrm{BbF}$ & Yes & Yes \\
\hline benzo(k)fluoranthene & $\mathrm{BkF}$ & Yes & Yes \\
\hline benzo(e)pyrene & $\mathrm{BeP}$ & Yes & Yes \\
\hline benzo(a)pyrene & $\mathrm{BaP}$ & Yes & Yes \\
\hline dibenz(a,h)anthracene & DBA & Yes & Yes \\
\hline Indeno(1,2,3-cd)pyrene & IPY & Yes & Yes \\
\hline benzo(ghi)perylene & BghiP & Yes & Yes \\
\hline coronene & Cor & Yes & Yes \\
\hline \multicolumn{4}{|l|}{ hopanes } \\
\hline $17 \alpha(\mathrm{H})-22,29,30$-Trisnorhopane & $\mathrm{C} 27 \mathrm{a}$ & Yes & Yes \\
\hline $17 \alpha(\mathrm{H}), 21 \beta(\mathrm{H})-30$-Norhopane & $\mathrm{C} 29 \mathrm{ab}$ & Yes & Yes \\
\hline $17 \alpha(\mathrm{H}), 21 \beta(\mathrm{H})$-hopane & $\mathrm{C} 30 \mathrm{ab}$ & Yes & Yes \\
\hline \multicolumn{4}{|l|}{ n-alkanes } \\
\hline n-tetracosane & $\mathrm{C} 24$ & Yes & Yes \\
\hline n-pentacosane & $\mathrm{C} 25$ & Yes & Yes \\
\hline n-hexacosane & $\mathrm{C} 26$ & Yes & Yes \\
\hline n-heptacosane & $\mathrm{C} 27$ & Yes & Yes \\
\hline n-octacosane & $\mathrm{C} 28$ & Yes & Yes \\
\hline n-nonacosane & $\mathrm{C} 29$ & Yes & Yes \\
\hline n-Triacontane & $\mathrm{C} 30$ & Yes & Yes \\
\hline n-hentriacontane & $\mathrm{C} 31$ & Yes & Yes \\
\hline n-dotriacontane & $\mathrm{C} 32$ & Yes & Yes \\
\hline n-tritriacontane & $\mathrm{C} 33$ & Yes & Yes \\
\hline
\end{tabular}


https://doi.org/10.5194/acp-2021-1007

Preprint. Discussion started: 8 February 2022

(c) Author(s) 2022. CC BY 4.0 License.

(c) (1)

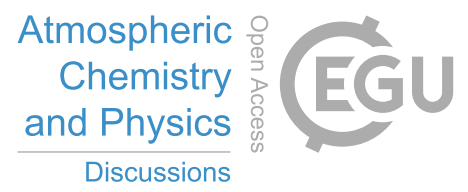

\section{Others}

levoglucosan

palmitic acid

LEVOG

Yes

Yes

stearic acid

PALMIA

Yes

Yes

cholesterol

STEARA

Yes

Yes

CHOL

Yes

Yes

731

732

733 


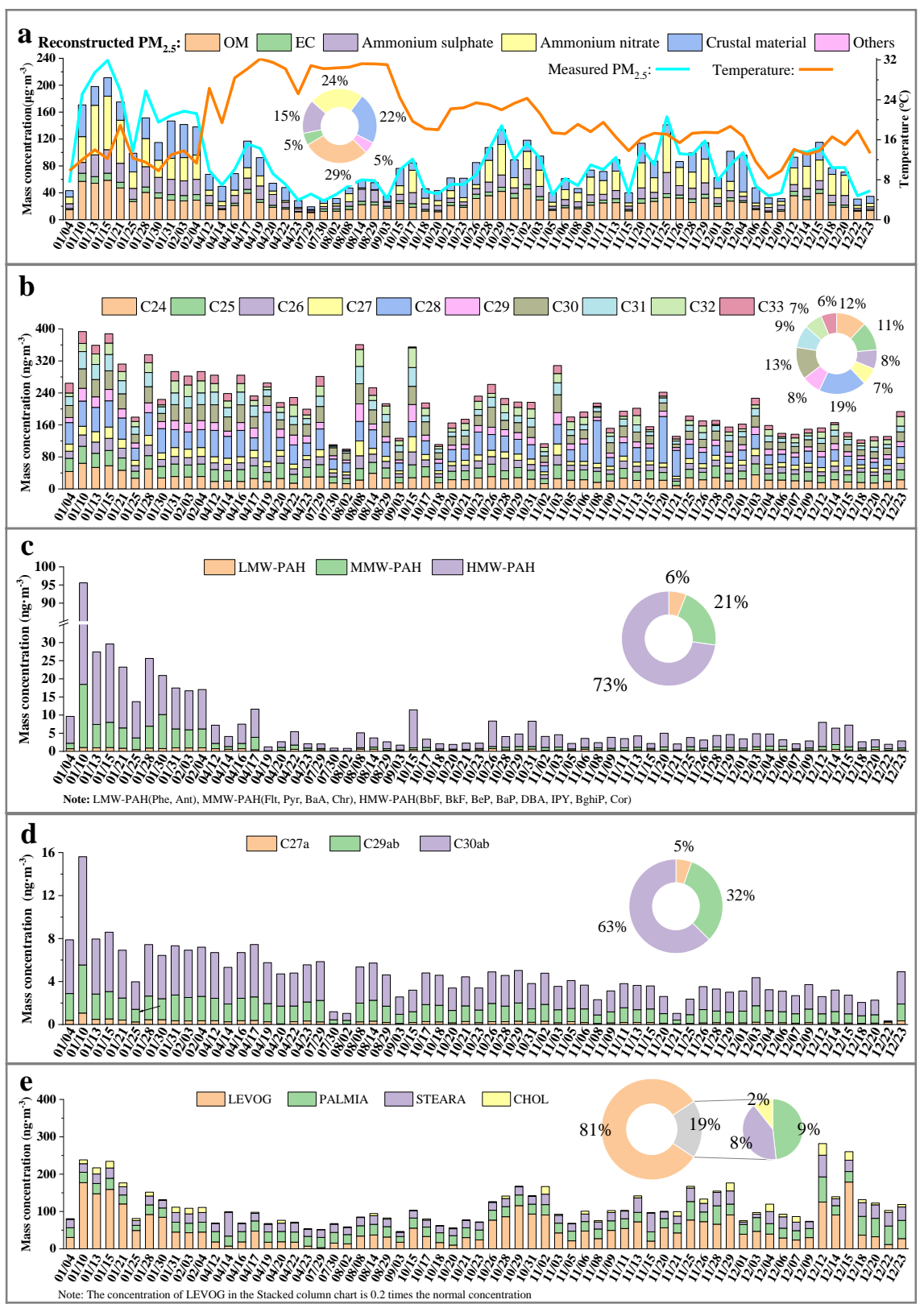

Figure 1. The daily concentrations of $\mathrm{PM}_{2.5}$, mass closure of main species, and organic components. and cholesterol. 


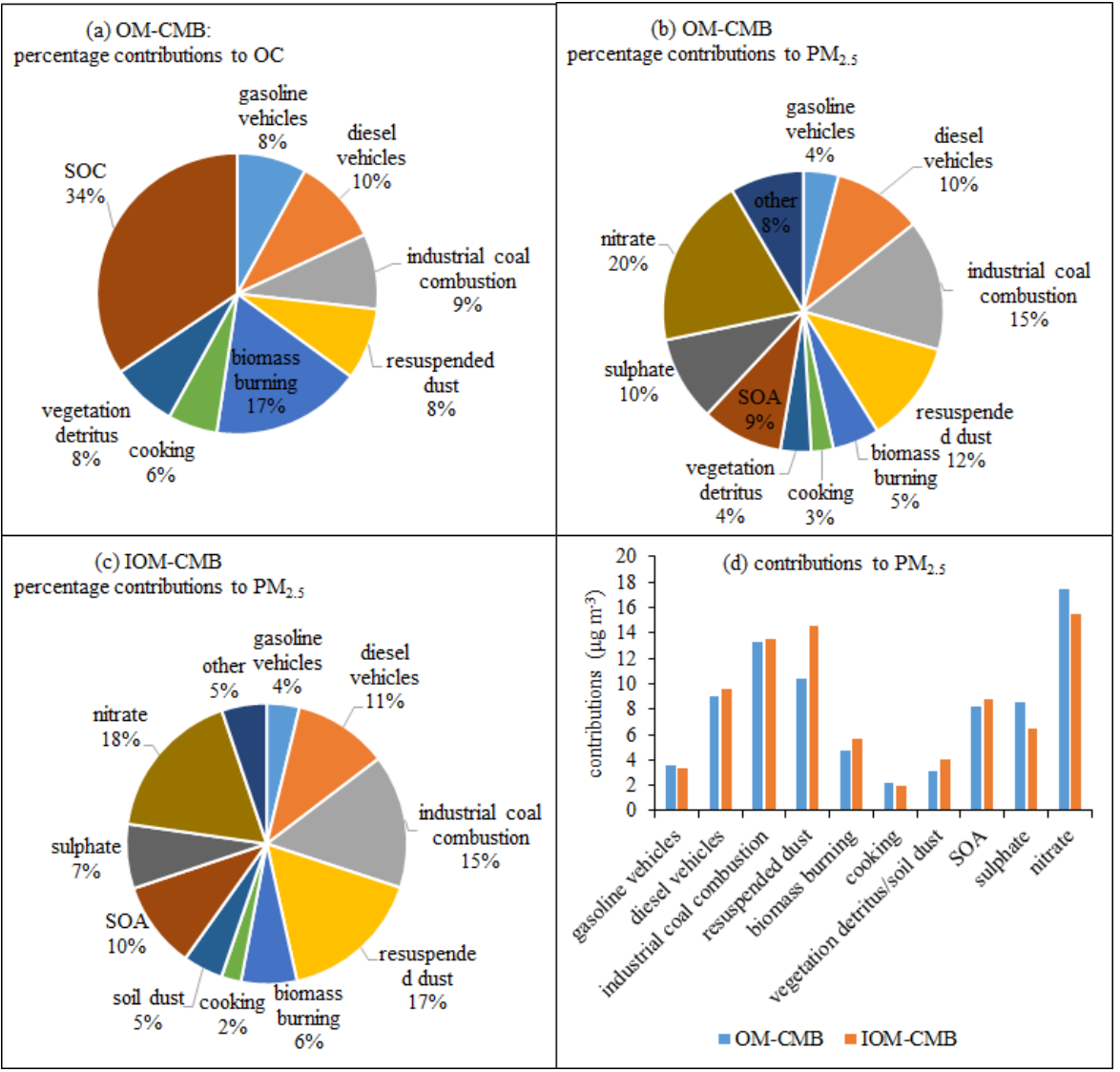

Figure 2. (a) The average of percentage contributions to $\mathrm{OC}$ estimated by the OM-CMB; (b) The annual average of percentage contributions to $\mathrm{PM}_{2.5}$ estimated by the OM-CMB; (c) The annual average of percentage contributions to $\mathrm{PM}_{2.5}$ estimated by the IOM-CMB; (d) Comparison of contributions to $\mathrm{PM}_{2.5}$ estimated by the OM-CMB and IOM-CMB. 


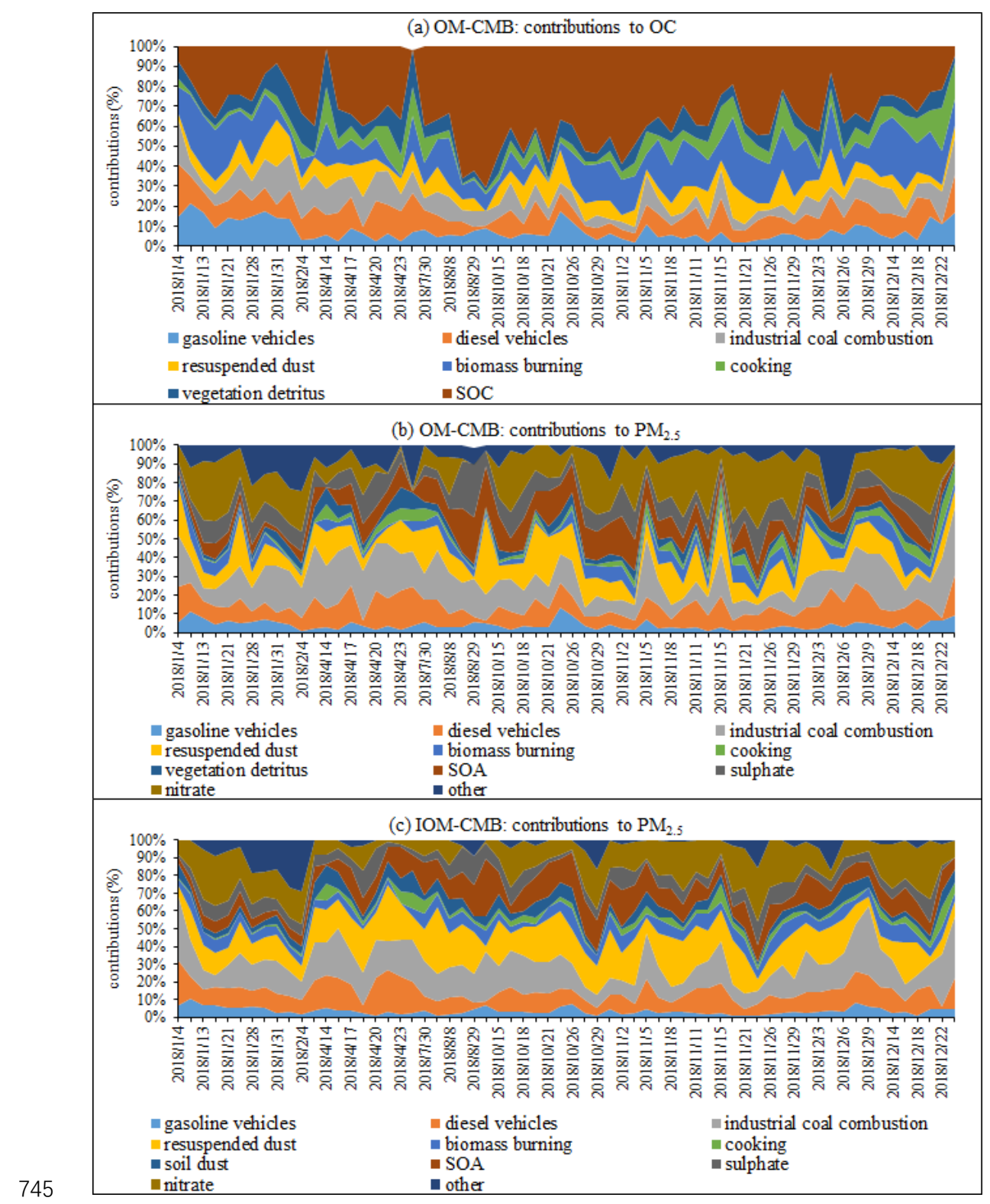

746 Figure 3. (a) Daily contributions to OC estimated by the OM-CMB; (b) Daily contributions to $\mathrm{PM}_{2.5}$ 747 estimated by the OM-CMB; (c) Daily contributions to $\mathrm{PM}_{2.5}$ estimated by the IOM-CMB. 


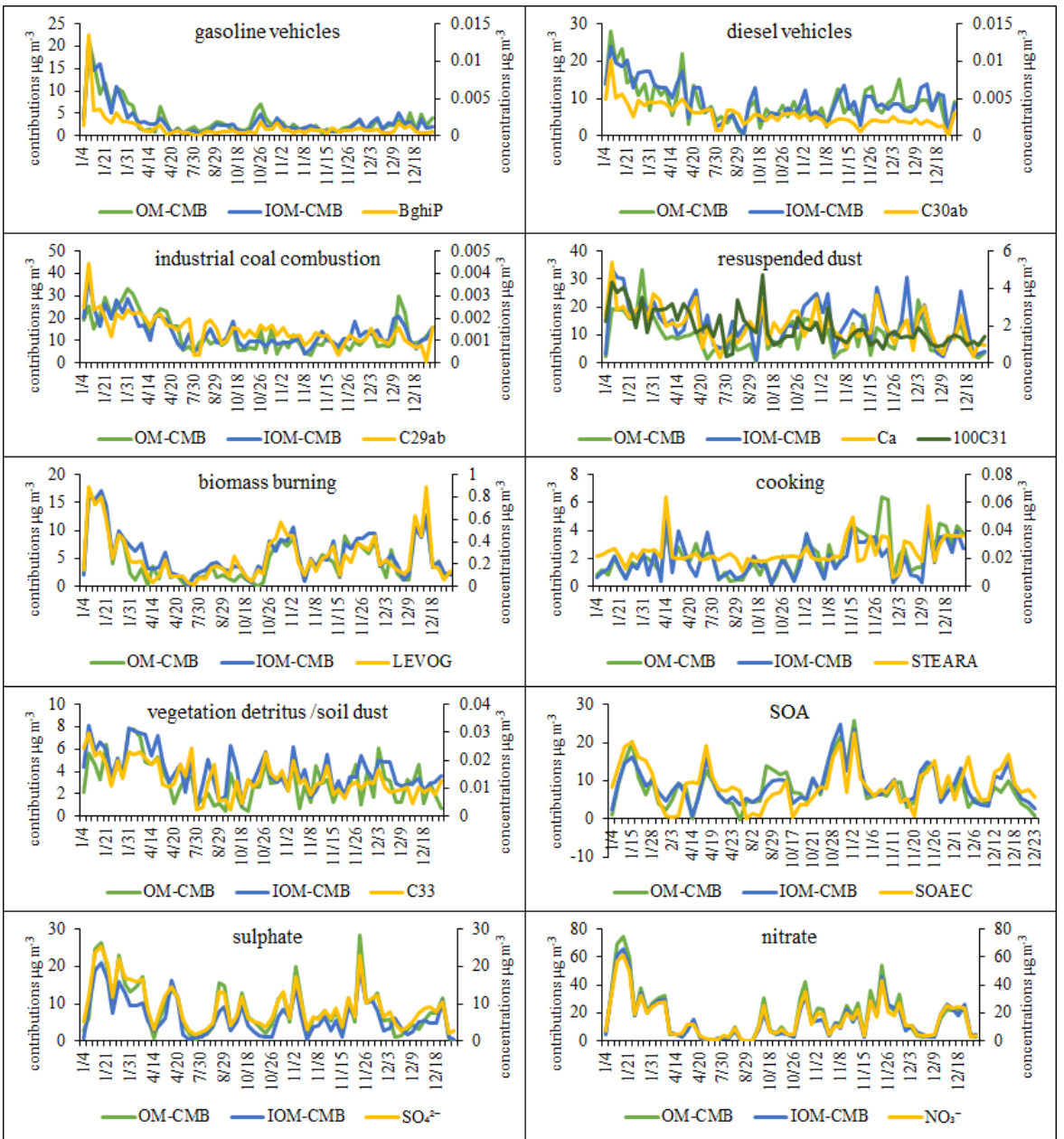

Figure 4. Comparisons among source contributions estimated by the OM-CMB and IOM-CMB, and corresponding markers. 